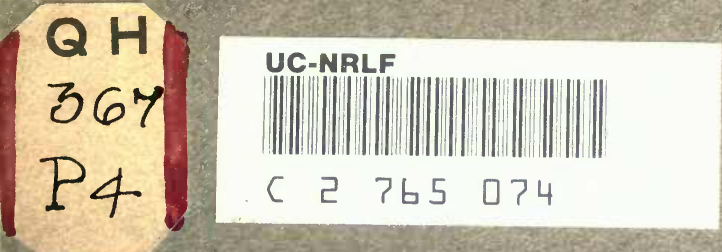




\section{GIPT OF}

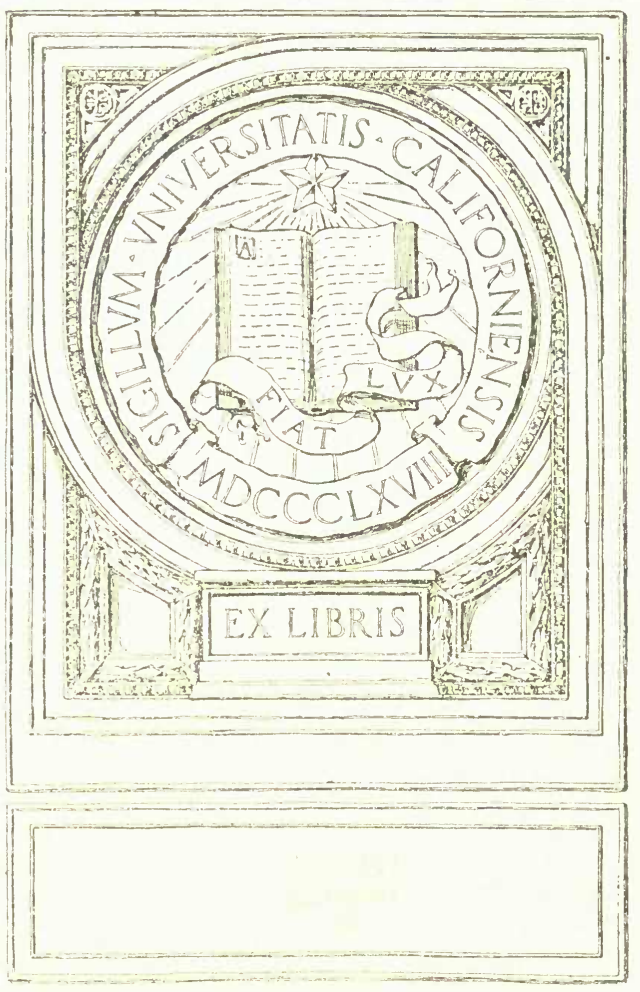




\section{N THE LAW OF IRREVERSIBLE EVOLUTION}

$\mathbf{B Y}$

BRANISLAV PETRONIEVICS, PH. D.

FROM THE SMITHSONIAN REPORT FOR 1918, PAGES 429-440

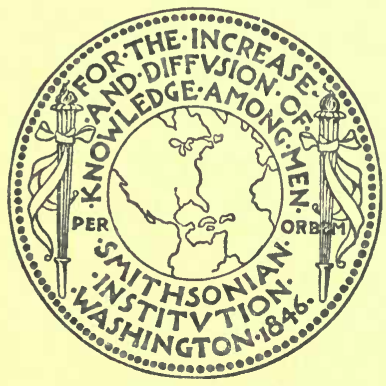

(Publication 2565)

WASHINGTON

GOVERNMENT PRINTING OFFICE

1920 
u 


\section{ON THE LAW OF IRREVERSIBLE EVOLUTION}

BRANISLAV PETRONIEVICS, PH. D.

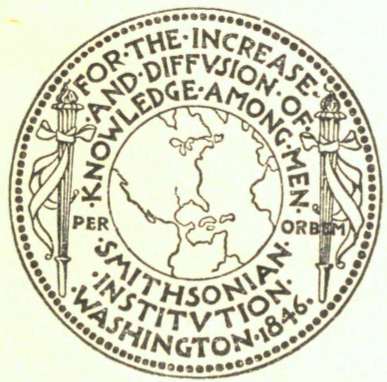

(Publication 2565) 



\title{
ON THE LAW OF IRREVERSIBLE EVOLUTION. ${ }^{1}$
}

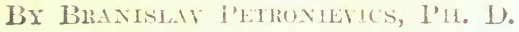

Louis Dollo, the great Belgian paleontologist, first publicly formulated in 1893 (Dollo, 4) his famous law of irreversible evolution, one of the most important laws of the evolution of organized beings.2 This law has often been debated and applied, but I do not know that anyone has attempied to set it forth, basing his exposition on Dollo's own works. This is what I propose to do here, adding to my account some critical remarks on the value of the law in question.

The law of irreversible evolution was stated by Dollo as follows:

An organism can not return even in part to a previous condition already passed through [déjà réalizé] in the series of its ancestors. (Dollo, 4 1). 16.5.) ${ }^{3}$

It is usually supposed that the law thus expressed applies only to parts and organs which are reduced or eliminated; but this is not correct. The law is much wider in its application, corering functional organs as well. In order to understand more clearly the far-reaching nature of Dollo's law we must make certain distinctions in the concept of organic evolution and give some definitions of them.

Organic evolution may be, as we know, mogressive, regressive. and mixed." If, during mixed evolution (which is the most wide-

\footnotetext{
1 Translated, with permisiom, by Gerrit S. Miller, jr., from Sienee Progress, Jammat, 1919.

"Ife previously stated this law in 1892, in his Cours autographie, ete. (Dollo, 1), the same year in a note which appeared in the Bulletin de lil soc. belge de Géol., ete. (Dollo, 2 ) and in an article which appeared in A. Giard's Bulletin scientifique de la France at de la Belgique (Dollo, 3).

${ }^{3}$ Later, Dollo expressed his law with greater exactitude:

"An organism never exactly renews a previous condition, even if it finds itself placed in an environment identical with one through which it has pasech. But, by virtue of the indestructibility of the past, it almays retains some trace of the intermediate stagcs which it has traversed." Dollo 17, p. 107, and 10. p. 413.) Let as note that Dolio dofinitely admits the reversibility of eonditions of existence: "Erolution is irrerersible as regariss

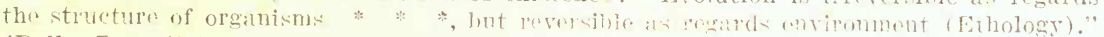
(Dollo, 7,1 . 15.)

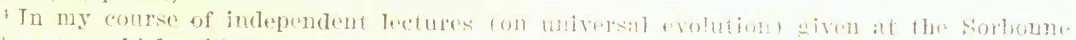

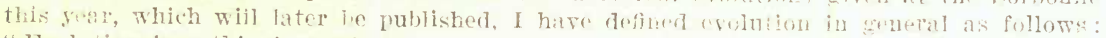

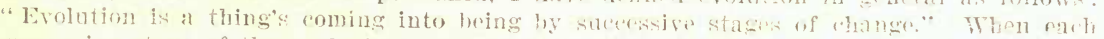

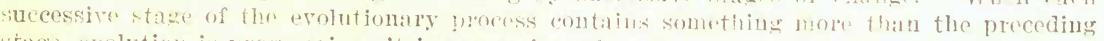

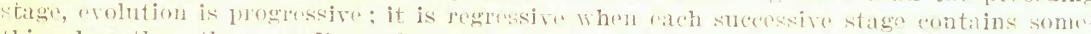

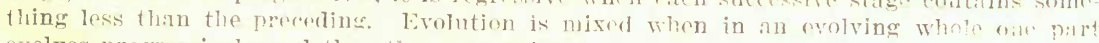
erolves progersicely and the other regressively.
} 
flead type in the fumatin of organic ewhtion! progre-ion prelominater, or. (1) put it in another way, if the final condition reached rople-nnt-plogles in amparison with the initial andition. we then

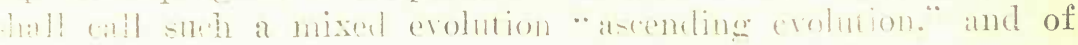

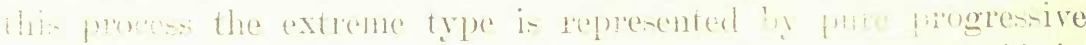

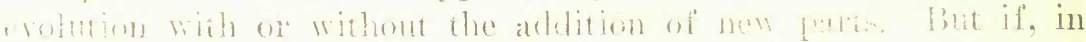

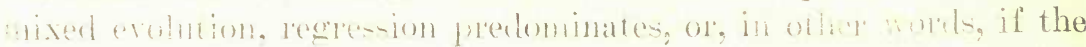

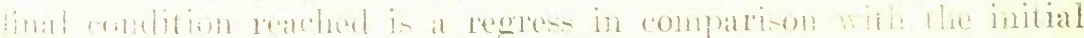

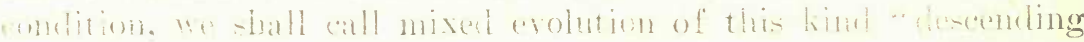

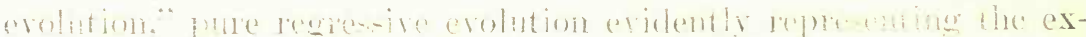

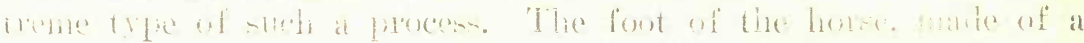

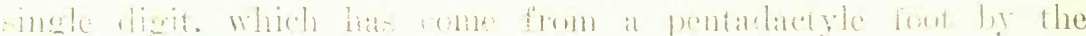

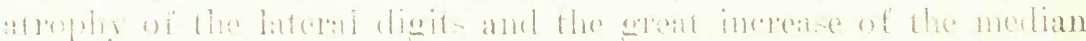

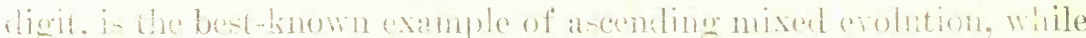

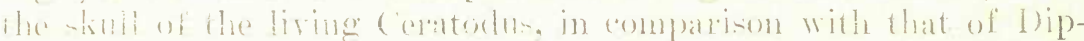

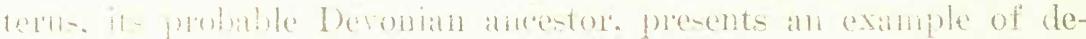
scemling nixnl awlutions.

Takine inte consteration on the one hand. the definitions which

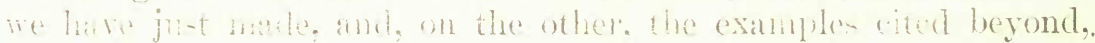

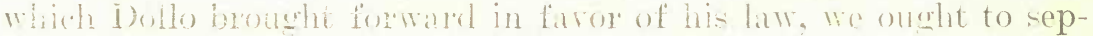

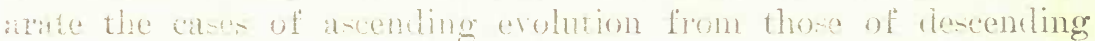

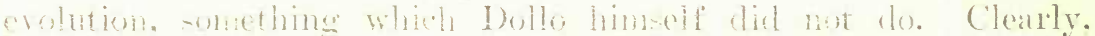

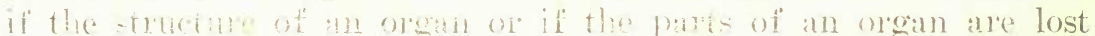

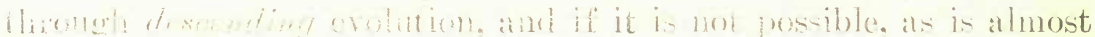

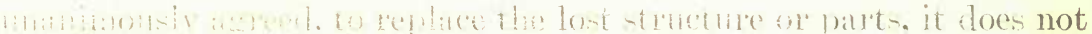

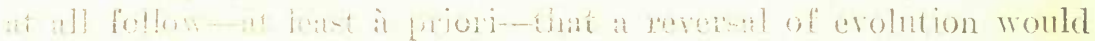

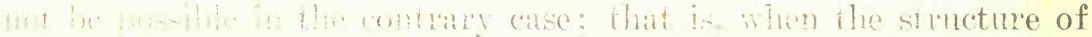

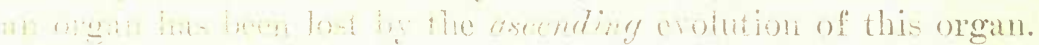

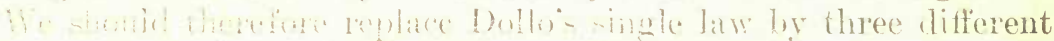

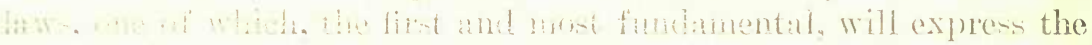

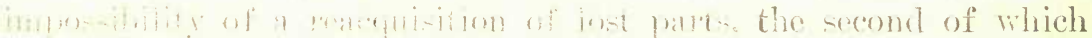

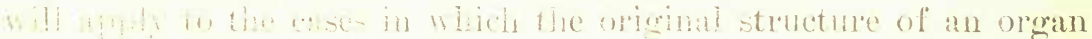

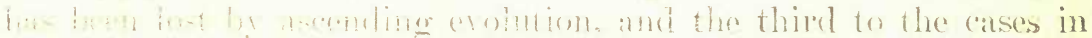

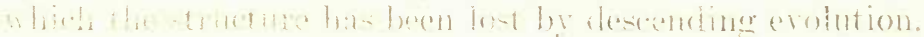

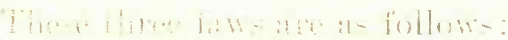

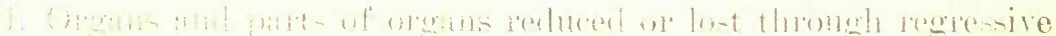

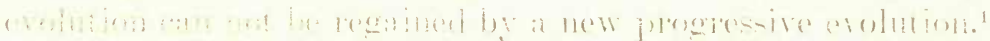

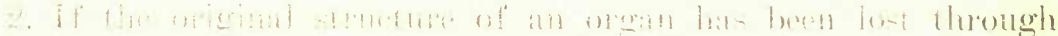

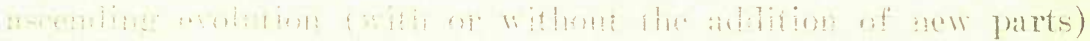

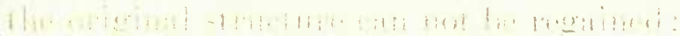

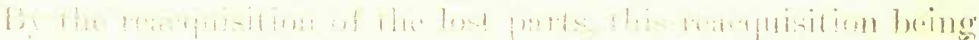

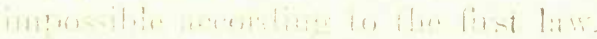

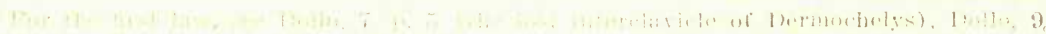

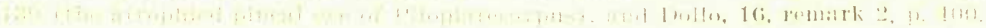


(b) By the regressive erolution of the new parts, the total clisappearance of these parts being impossible.

(c) By the ascending evolution of these new parts in a new direction.

3. If the original structure of an organ has been lost throngh descending evolution (with or withont the loss of parts), this original structure can not be regained:

(i) $\mathrm{By}$ the reacquisition and progressive evolution of the lont parts, this reacquisition being impossible according to the first law.

(ii) By the ascending erolution of the nonperheed parts in a new direction.

(iii) By the ascending erolution of altogether new parts.

II.

The various cases falling under these three latrs we wish now to explain by examples found in the writings of Dollo.

For the first law examples are rery numerous. The birds lost their teeth during the Cretaceous period; no subsequent bird has been able to regain these lost parts. The mandible of mammals comsistof a single piece homologous with the dentary part of its reptilian ancestors; no mammal has been able to regain the lost other parts of the reptilian jaw, etc.

But the examples that especially demonstrate the validity of the first law are those in which the return to ancestral conditions wou?d necessitate the reappearance of parts which an organism has lost. As these examples are at the same time illustrations of the two other laws we shall deal with them in connection with these laws.

The best-known example of the first alternative under the second law is the psendo dentition of Odontopteryx, an Eocene fossil bird. Instead of the true teeth that have been lost, Odontopteryx has the margin of the beak and of the lower mandible dentate like a siw.

The most striking example of the second alternative under the second law is the pelvis of Triceratops. The dinosaurian anectors of Triceratops had become adapted to bipedal life, and therefore were possessed of a very long and very narrow icchinm and of a pubis provided with a postpubis which was similarly very long and very narrow (Dollo, 10, p. 444). In its secondary adaptation to quadrupedal life Triceratops was not able morphologically to regain the triardiate pelvis of its far-distant quadrupedal ance-tors, for it has retained traces of the bipedal phase in the rudimentary posipubis and in the narrow, recurved ischium. That is to say, the postpubis, the new structure acquired during bipestal life, could not totally disappear. and the new form of the i-chimm conld not disappear either (Dollo, 10, p. 446).

The most important and most obrious example of the third alternative under the secomd law is also formd in a dinosanr. nearly related 


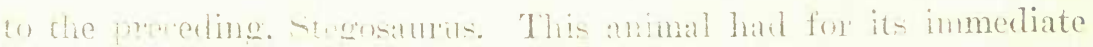

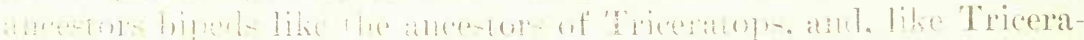

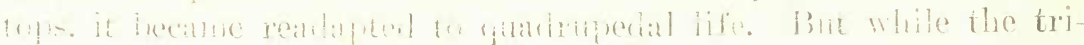

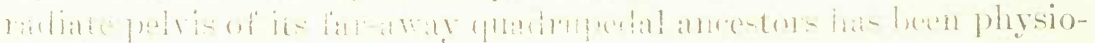

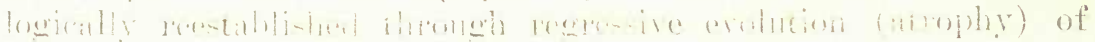

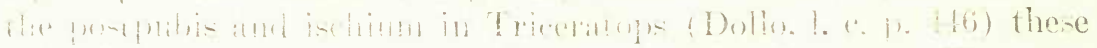

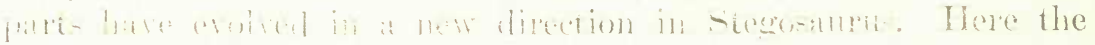

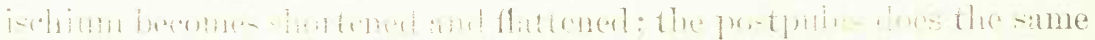

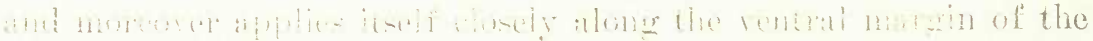

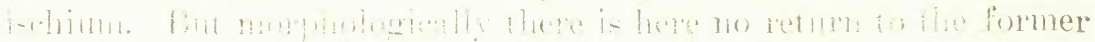

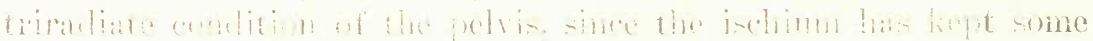

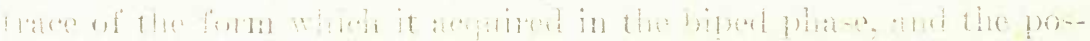

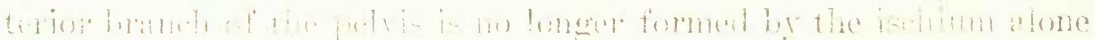

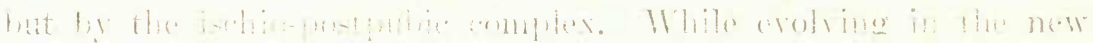

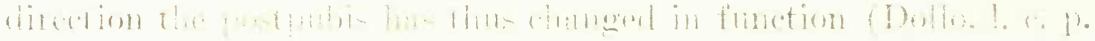
$(17)$

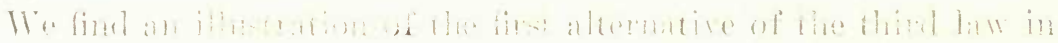

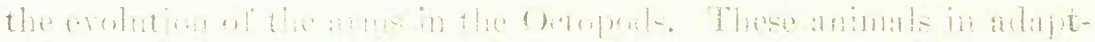

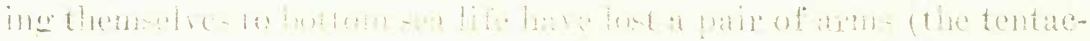

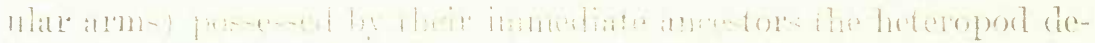

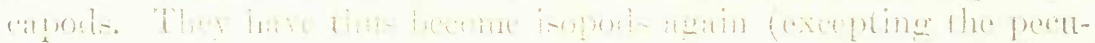

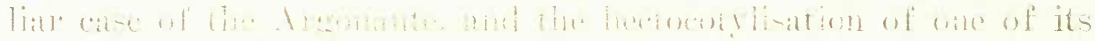

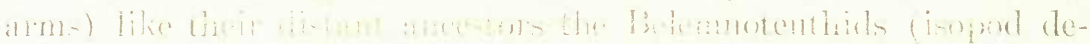

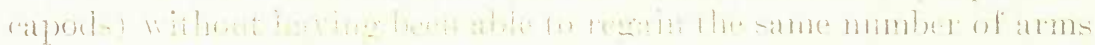

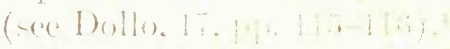

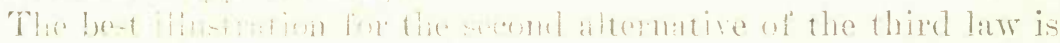

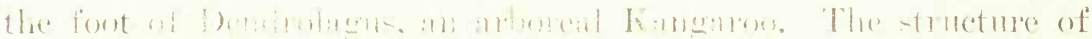

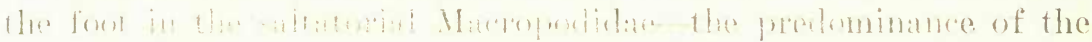

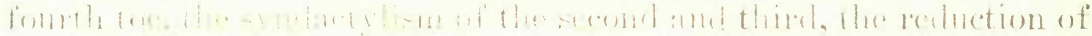

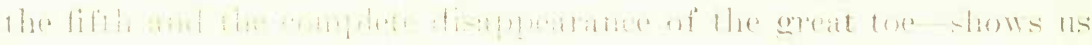

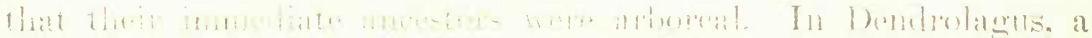

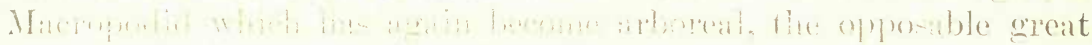

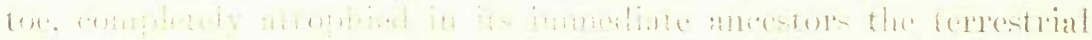

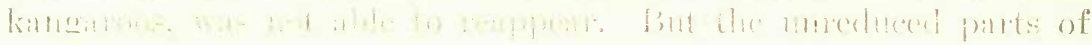

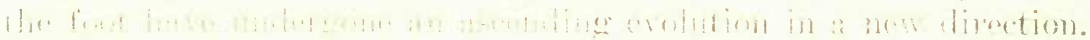

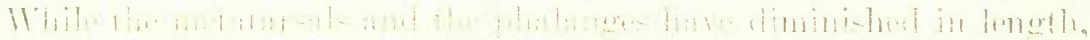

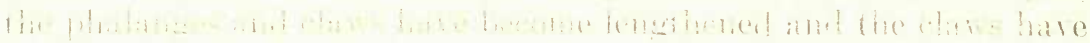

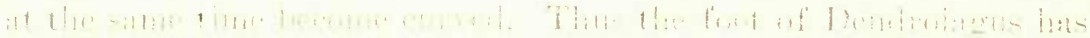

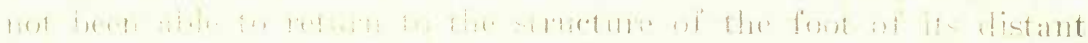

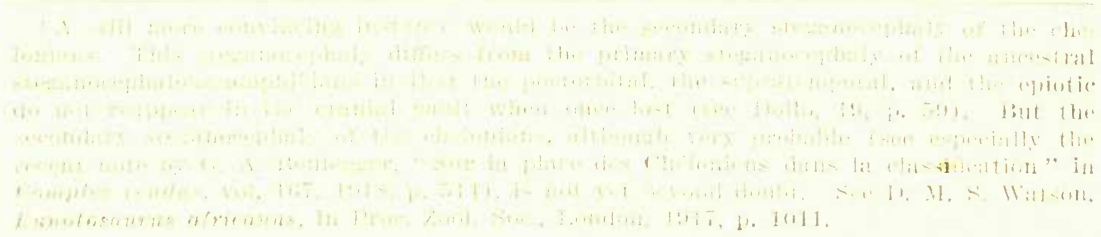


ancestors, which possessed an opposable great toe, syndactyly of the second and third toes, dominant fourth toe, and reduced claws. (See Dollo, 6, pp. 194 and 199.)

Finally, for the third alternative of the third law we have an illustration in the secondary carapace and plastron of the turtle Dermochelys. The distant ancestors of this turtle were, like it, seaturtles; its reduced primary plastron (a ring formed of four pieces) and its still more reduced primary carapace (represented by the nuchal plate alone) bear witness to the fact. When adapting themselves to littoral life the immediate ancestors of Dermochelys reacquired a carapace and a plastron, but this carapace and plastron are entirely new structures of superficial dermal origin. Readapting itself to marine life Dermochelys has preserved this carapace and plastron of its immediate ancestors, although both are already much reduced. (See Dollo, 7, pp. 9-14.)

\section{III.}

The importance of the law of irreversible evolution is multiple. In the first place, this law has a phylogenetic application, that is, it places us in position to reconstruct, with the often insufficient paleontological material which we possess, phylogenetic series which, if they are not true series are at least series which represent indubitable evolutionary stages. Its ethological application is yet more considerable. It is often the only means of determining the conditions of existence and the method of adaptation to life of fossil organisms. But sometimes this law has a morphological importance also, because by using it we can distinguish homologies from mere analogies. Finally Dollo has shown that it can act also as a guide in classification, that it therefore has a systematic application.

The most important phylogenetic application of the law was made by Dollo in the difficult question of the phylogeny of the Dipnoi. Dollo's very ingenious paper on this subject (Dollo, 5) should be considered a model presentation of the philosophic point of view in the new paleontology. Before Dollo this subject was in a truly chaotic state, one of the most eminent paleontologists having declared Dipterus, the oldest and most primitive type, to be the most specialized. ${ }^{1}$ Nowhere else has the conception of the irreversibility of erolution given such brilliant results. Since this conception expresses the idea that we never fully return to an ancestral structure it can be used to determine whether a particular condition is primary or secondary. Consequently it can be used to decide upon the direction of evolution when we have a series containing a sufficient num-

1 See A. S. Woodward, Catalogue of the Fossil Fishes in the British Museum, pt. 2, 1891 , p. XX. But aiter lollo published his important memoir Woodward accepted his conclusions. Sie his prosilential adoress to the section of Geology, in Nature, vol. 81, 1909, p. 292 (and Jollo, 16, rem. 2, p. 387). 
ber of terms intermediate between the extremes (Dollo, 5, p. $97^{1}$ ). Just such a series we possess in the paleontological series of the Dipnoi: Dipterus ralenciennesi, Dipterus macropterus, Scaumenacia, Phaneropleuron, Uronemus, Ctenodus, Ceratodus, Protopterus, Lepidosiren (l. c., p. 88). Dollo shows that the structure of the tail as well as that of the top of the head, the squamation, the pugular plates, the opercular apparatus, the ganoin, and the ossification of the mandible, the suborbital band-all this proves that the course of evolution has been in the direction from Dipterus to Ceratodus. and not the opposite (l. c., p. 89-97). It is especially by the structure of the tail that the concept of irreversibility is illustrated. In a long and thorough treatment of the subject Dollo shows (1. c., pp. 89-97) that the diphycercal tail of the Dipnoi (and of the other known ancient and modern fishes) is a secondary diphycercal tail whose morphological value in the Dipnoi (the second dorsal fin, the second anal fin) is not equivalent to the morphological value of the primitive diphycercal tail (caudal fin). In this secondary diphycercal condition there is therefore no return to the primitive structure.

The most important other cases of phylogeny which Dollo has considered are the phylogeny of the sirenians (Dollo 3, p. 119), the phylogeny of the Leather-backed turtle (Dollo, 7, p. 9), and the phylogeny of the Holocephali (Dollo, 13, p. 107).

One of the most important cases with regard to the ethological application of the law of irreversibility is found in the memoir on the Dipnoi. If it be assumed that Dipterus comes from Ceratodus, as the latter is an adaptation to life in turbid water, it would be necessary to suppose either that Dipterus represents an adaptation to life in mud (excessively turbid water), or else that it represents a return to life in clear water. The first alternative being that of Lepidosiren, the second is the only one which remains open for discussion (Dollo, 5, p. 99). But, putting aside paleontological and purely ethological reasons, the law of irreversibility is sharply opposed to such a view.

"Would the lost ganoin return? Would the cephalic shield resolve itself into its ancestral elements? Would the suborbital band with its ossicles in varying number become once more a solid arch? Would the opercular apparatus resume its original dimensions? Would the vanished jugular plates reappear?" As all of these structures are reduced in Ceratodus (1. c., 1. 100), Dipterus can only represent a primary adaptation to life in clear water, that is to say it is purely a fish ("the most pisciform of Dipnoi," 1. c., p. 101).

${ }_{1}^{1}$ Discussing the subject of the phylogeny of the IIolocephali (Dollo, 13, pp. 107-108), Dollo says: "The idea of the irreversibility of evolution, which has led me to the results that I have just demonstrated, has once more shown its usefulness. Without it one would le led to assert that specialized organisms could become primitive again and then onee mol specialize themselves in the same or another direction. Such an assumption, unless supported by absolutely complete paleontologieal series-which we are far from possessing-would destroy all possibillty of discovering phylugeny, the main whject of mor1) hology." 
Another important instance of the ethological application is furnished by the bipedal habits of the immediate ancestors of Stegosaurus and Triceratops.

If evolution were reversible these two dinosaurs would have exactly regained their former quadrupedal structure, and there would have been no way to distinguish their secondary quadrupedal existence from the first (Dollo, 10, p. 448).

The other most important cases of ethological application are: The secondary adaptation to the swimming sea life of the Pycnodonts (Dollo, 17, pp. 108-9), the secondary adaptation to the swimming sea life of the Trilobites Dephon and Aeglina (Dollo 16, pp. 410 and 412 ), etc.

Among the instances of the morphological application of the law, that of the secondary abdominal ventral fins in the teleosts has a special importance. As is known, the ventrals of teleosts may be either abdominal or thoracic or jugular. But among the abdominal ventrals we have two types-those which have no connection whatever with the pectoral girdle, and those joined to the clavicular symphysis by a ligament. As there is no reason for the presence of this ligament in situ we have to conclude that it is the degenerate remnant of a former direct connection with the pectoral girdle. In conformity with the irreversibility of evolution the ventrals in again becoming abdominal have kept the connection with the clavicular symphysis which they acquired when occupying a thoracic or jugular position (Dollo, 14, p. 139).

The other important instances of the morphological application of the law are: (1) The very anteriorly placed choanae of the sea turtles (Dollo, 8, pp. 817-820), (2) the longirostral and brevirostral condition in Crocodilians (Dollo, 12, p. 85), etc.

Finally, we must mention the one instance in which Dollo has used his law in systematic work-the Ptyctodonts. Before Dollo these fossil fishes, then known from their dental plates only, had been placed among the Holocephali. In his important memoir on this subject (Dollo, 13) Dollo showed that, by virtue of the law of irreversible evolution, the Ptyctodonts can not be regarded as Holocephali and that they ought to be treated as Arthroderes. Since then Dollo's conclusion has been wholly confirmed.

Although the empiric evidence for the validity of his law has been abundant and varied, Dollo was not satisfied with such a wholly empiric demonstration. He has attempted to give a deductive demonstration as well. He says:

The Irreversibility of Evolution is not, as many have believed it to be. merely an empiric law based purely on facts of observation. But it has deepseated causes which carry it in final analysis to a question of probabilities, as in the case of the other laws of nature. Evolution being a summation of exactly determined individual variations in an exactly determined order, to have it reversible would be to admit the possibilty of the intervention of causes exactly the inverse of those which produced and fixed the individual variations from which the first transformation arose, and in an exactly inverse 
order-cincumstances too complex for it to be imagincel that they are ever realized. (Irollo, 19. 1. 59, renl.; ser also Inollo, 3, 1). 127.)

And, when speaking of the impossibility of the descent of Dipterus from Ceratodus (Dollo, 5, p. 100, the passage referred to above) he says:

And let it be noted that it is here a question not of one isolated character, but of a whole group of characters, something that is much more serious so far as irreversibility is concerned $* * *$ But it is particularly in its action on elements as multiple as these that we "an allirm with rertainty that (solution is not reversible (1. c. rem. 72, p. 122).

The irreversibility of erolution becomes, therefore, according to I) ollo, the more probable as the number of element incrases, and it is practically a necessity when the number of elements is considerable.

\section{TT.}

Having explained the law of irreversible evolution, the various cases which it makes cleas, also its applications, and its logical basis, we now wish to make some critical remarks on the varions a-pects of the law.

In the first place, its logical basis. The deductive demonstration. of his law, attempted by Dollo, is very doubtful. As to the number of element on which evolution acts, it is not a question of cells, but of organs and parts of olgans (because it is only these last which have their peculiarities determined in the germ), and the number of these oroms and parts is not relatively areat even in the most complex organi-n. But, if we consider the much greater number of individuals in which the organs and parts of organs show indiviclual variations, the chance that they will vary in different directions and consequently also in inverse directions becomes pos-ible. It is only if we assert that individual variations are relatively not rery munerous-predetemined-that this course of reaoning fonder on pure probability becomes weak. In that ease, however, the law of irrerersible evolution is not the result of numerical probability, but the result of unknown internal causes of (1) Manile evolution.

There i-. therefore, no logral necessity in the law of irreversible crolution. and this law remains a purely empirical rule. Let us now - re how mueh the three laws of this evolution are confirmed by axperienere and to what extent we shomld expect posible exceptions.

As to the first law, this law appears to be without exceptions so far as it applies to lost oreans and parts. For the losis of an organ of eff a fat having becone final hy the loss of the corresponding

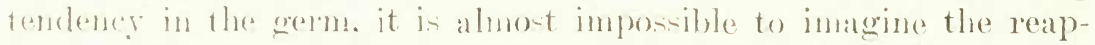
pertance of this tendency. learing in mind, on the one hand, the

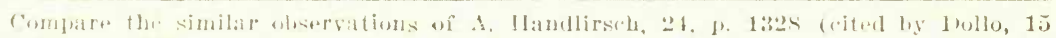
r.m. $121,1,4: 9$, 


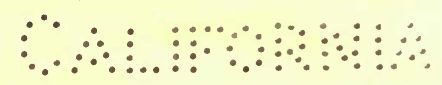

IRREVERSIBIE EVOLUTION-PETRONIEVICS.

difficulty of producing new tendencies in the germ by the influence of external causes, and on the other the degree of correlation that would be needed among these tendencies. When it is a question of the reduction of an organ or part, two alternatives must be distinguished. If the reduction has gone so far that the corresponding tendency in the germ is rerging on complete disappearance, the reduced organ or part will find itself practically in the same condition as if it were already lost. But if their reduction has not reached to such an extreme their evolution in an inverse direction will not be impossible.

For the second law we must distinguish between the case of a single part and that of a complex organ. The regressive evolution of a single part, if during this evolution and the preceding progressive erolution no change of form has taken place, could clearly lead back to the point where the progressive erolution started. And the regressive evolution of a single part, if the corresponding arrangement in the germ is not too much enfeebled, could evidently also be followed by a new progressive evolution. But if a change of form has taken place during the first progressive evolution, and if this change of form has been so great that a change in the corresponding arrangement of the germ has been necessary, then neither the regressire erolution following the original progressive evolution will be able to lead back to the point of departure of the latter, nor will a new progressive evolution have the power to accomplish it, because to do so would necessitate the return to a disappeared condition. If, for instance, a tooth has first increased in size and afterwards diminished without change of form this tooth will be able by diminution to assume the dimensions which it had at the beginning of its increase, and a new increase of the same kind will not be impossible (if the reduction has not gone too far). But if the increase in size has been accompanied by a radical change of form, if, for instance. a conical tooth has become laterally compressed, then a return to the conical form will not be possible either during its diminution ${ }^{1}$ or (luring a new increase in size.

In the case of a complex organ Dollo asserts that its return to the previous condition through the action of regressive evolution is impossible on account of the "indestructibility of the past." But if a single reduced part of an organ is regarded as the supposed reason why reversibility is impossible. we are able to affirm almost with certainty that in such a case the indestructibility of the past does not exist, because it would find itself in contradiction with the well es-

1 This impossibility is exactly what W. D. Matthew supposes to have happened during the evolution of the Frlitae when he supposes that the felines come from Dinictis, a primitive saber-toothed cat (see W. D. Matthew, "The l'hylogeny of the Feidae," Buil. Amer. Mus. Nat. IIist, vol. 2S. 1910 , p. $290 \mathrm{~s})$. Seott has clearly had a glimpse of the fact that this ply logeny contradiets the law of irreversible evolution isee $\Pi$. P. Scott, 2S, p. 5*0 s).

$136650^{\circ}-20-29$ 
tablished law of the necessary regressive evolution of nonfunctional parts and organs. The reversibility of the ascending evolution of a complex organ, when it depends on a reduced part, is therefore not impossible (we can suppose, for instance, that the secondary ventrals of teleosts will return in the future to their original condition through the complete disappearance of the clavicular ligaments).

In the case of a nonreduced part, whose form has, however, changed during ascending evolution, the indestructibility of the past again does not exist in the strict sense, the nonreduced part being able to change its form again by a new progressive evolution, although the original condition of this part, and consequently the original condition of the organ in question can not be reestablished. The pelvis of Triceratops may be taken as an example. The postpubis of this pelvis exists in a very rudimentary condition, and as rudimentary parts tend to disappear, the postpubis certainly would have disappeared if Triceratops had lived long enough. It is therefore only its recurved ischium, very different in form from the ischium of its distant tetrapod ancestor's, which was able to prevent Triceratops from recovering its original pelvis.

Finally, if there is an ascending evolution of nonreduced parts (pelvis of Stegosaurus) it is the change of function which saves these parts from a regressive evolution; the indestructibility of the past does not exist here either. And it is clear that the same reasoning is also applicable under the third law to the evolution of a complex organ.

To sum up: The irreversibility of the evolution of a complex organ depends entirely on the irreversibility of the erolution of the reduced or nonreduced individual parts which enter into its composition, and the second and third laws are not without exceptions in this respect any more than the first; as we have seen, it is the germinal base of the first law which underlies the entire subject.

As I said at the beginning, most naturalists know Dollo's first law only. This is only a part of his general law, although the most important and most certain part. ${ }^{1}$ This general law, in spite of the possible exceptions, has an extraordinary importance for biological philosophy and evolutionary philosophy in general. Dollo will al-

${ }^{1}$ Besirles the law of irrerersible erolution Dollo has formulated (see Dollo, 4, p. 165) two other laws-that of discontinuous evolution (before II. de Vries) and that of limited evolution. In his subsequent writings Dollo has only rarely touched on these two other laws (on the law of limited 'volution see Dollo, 7, p. 9, Dollo, 8, p. 813 and p. 820, Dollo, 9, p. 131; on the law of discontinuous evolution see Dollo, 5, rem. (66), p. 120; Dollo. 7 , rem. (11), p. 9 ; and Dollo, 17, pp. 139-140). 
ways be regarded, like Cuvíer before him, as the founder of a great law of the organic world. ${ }^{1}$

\section{LITERATURE.}

1. L. Dollo, Cours autographié sur l'érolution du squelette des Vertébrés. Leçons faites à l'Institut Solvay (Université de Bruxelles) en 1891-2.

2. - Sur l'origine de la nageoire caudale des Ichthyosaures. Bulletin de la société belge de Géologie, de Palénntologie ot de IIndrologic. vul. 6, 1892, Procès-verbaux, N1. 167-74.

3. - Sur la morphologie des côtes. Bulletin scientifique de la Fromer et de la Belgique, publié par A. Giarol, Paris, vol. 24, 1892, pr. 113-29.

4. Les lois de l'évolution. Bulletin de la sor. brlge de céot., ete., vol. 7, 1893, Procès-verbaux, pn. 164-6.

5. - Sur la phỵlogénie des Dipneustes. Bulletin de la soc. belge de Génl., etc., vol. 9, 189.5, Mémoires, pr. 79-128.

6. - Les ancêtres des Marsupialax, étaient-ils arboricoles? dliscellanées biologiques dédiées au Prof. A. Giand, Paris, 1s.)9, pp. 185203.

7. - Sur l'origine de la Tortue Lutī (Dermochelys coriaceal). Bulletin de la société royale des sciences médicules et luaturelles de Bruxelles, 1901, separate, pp. 1-26.

8. - Sur l'evolution des Chéloniens marins (Considérations bionomiques et phỵlogéniques). Bulletin ale l'A dudémie royale de Belgique, Classe des Sciences, 1903, pp. S01-50.

9. Un nomvel opercule tympanique de Plioplatecarpus (Mosasaurien plongeur). Bulletin de la soc. belge de Géol., etc., vol. 19, 1905, Mémuires, pp. $125-31$.

10. Les Dinosauriens adaptés a la vie quadrupède socondairr. I3ulletin de la soe. belge de Géol., etc., vol. 19, 190., Mémoires, 1ll. 441-8.

11. Le pied de l'Amphiproviverra. Bulletin de la soc. belge de Géol.. etc., vol. 20, 1906, Procès-yerbaux. pp. 166-9.

12. - Nouvelle note sur les reptiles de l'Eocène inférieur do la Belgique et des régions voisines (Eosuchus Lerichei ot Eospluargis gigas). Bulletin de la soc. belge de Géol., etc., vol. 21, 1907. P'ocè-verbaux, Pr. 81-..

13. Lus Ptyctodontes sont des Arthodères. Bulletin de la sor. brlge de Géol., etc., vol. 21, 1907, Mémoires, pl. 97-108.

14. Les Téléostéens à ventrales ablominales secondaires. Jerhandlungen der k. li. zool.-botun. Gesellschuft in Wien, vol. 59, 1909. 11). 13.)-40. 15. - Les poissons Voiliers. Zoologisehe Jahrbïcher, Abtheilung fïr systematik, vol. 27, 1909, p). 419-38.

16. La Paléontologie éthologigue. Bulletin re la sor. belge de Génl., ote., vol. 23, 1909, Mémoiros, pp. 377-421.

17. —ues Céphalopoles adaptés à ja vie nectique secondaire et à la vie benthique tertiale. Zoologische Jahrbürher, Supplement vul. 1. ( Festschrift, J. W. Spengel, vol. 1), 1912, pr. 10\%-40.

18. - Globidens Fraasi. Archires de Biolofie, vol. 2s, 1913. 11). Gon-26.

19. ___ Porloconemis congolensis et l'évolution des Chélonicns fluviatiles. Annales qu Musée du Congo Belge, Bruxelles, 1913, 11), 49-6.5.

20. A. Giard, Les tendances actuclles de la morplobogie. Rorne soientitique, 1905, pp. 171-2.

${ }^{1}$ To the list of Dollo's writings on the law of irreversibu (xolution $I$ :m adding the titles of some sther papers (most of them already cited by Dollo) whose authors have discussed or applied this law. Among these treatises the important book by O. Abel, Grundzüge der Paloobiologie der Wirbeltiere, 1912, deserves special mention lecause it contains nearly all the nxamples eited hy Dollo and many others bedides. Dollo's law is discussed, pl). (61fi-fis. 
21. G. v. Arthaber, Reiträge zur Kenntniss der Organisation und der Anpassungserscheinungen des Genus Metriorhynchus. Beiträge zur Palcontologie und Geologie Oesterreich-Ungarns und des Oricnts, 1906, p. 301.

22. CH. Dépéret, Les transformations du monde animal, 1907, pp. 243-4.

23. F. v. Huene, Die Diwosaurier der europäischen Triasformation, 1908.

24. A. Handlirsch, Die fossilen Insekten und die Phylogenie der rezenten Formen, 1906-8, vol. 2, p. 1328.

25. H. F. Osborn, The Age of Mammals, 1910, p. 34.

26. K. Diener, Palieontologie und Abstammungslehre, Sammlung Göschen, pp. 98. $110-14$

27. O. Abel, Grundziige der P'alieobiologie der IVirbeltiere, 1912.

2S. W. B. Scott, A History of land Mammals in the Western Hemisphere, 1913.

29. R. S. Lull, Orgunic Evolution, A Textbook, 1917, 1, 280 and 1), 572. 



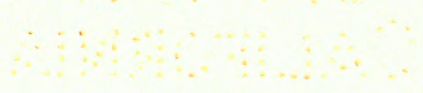



T 
Pamph Petronierics, 3 .
Gaylord
ible evolution

Maker.

Syracuse,

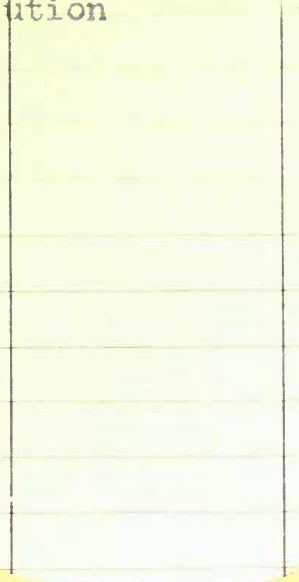

$521: 385$ 
